\title{
EFFECT OF BALANCED FERTILIZATION IN PUDDLED RICE ON THE PRODUCTIVITY OF LENTIL IN RICE-FALLOW SYSTEM UNDER ZERO TILLAGE
}

\author{
P.K. Bandyopadhyay ${ }^{1^{*}}$, K.C. Singh ${ }^{1}$, K. Mondal ${ }^{1}$, R. Nath ${ }^{2}$, N. Kumar ${ }^{3}$ and S.S. Singh ${ }^{3}$ \\ ${ }^{1}$ Dept. of Agril. Chemistry and Soil Sci., Bidhan Chandra Krishi Viswavidyalaya, Mohanpur, Nadia, West Bengal, \\ India \\ ${ }^{2}$ Department of Agronomy, Bidhan Chandra Krishi Viswavidyalaya, Mohanpur, Nadia, West Bengal, India \\ ${ }^{3}$ Indian Institute of Pulse Research, Kanpur-208024, India \\ ${ }^{*}$ Corresponding author: pkb_bckv@rediffmail.com
}

Key words: Stubble residues, Mulch, Moisture stress, Leaf relative water content, Water use efficiency

\begin{abstract}
Lentil (Lens culinaris Medik) predominantly grows under rainfed conditions under residual soil moisture in most of the rice-fallows in India with low productivity. Imbalanced NPK $\left(\mathrm{N}_{1}\right)$, recommended dose of NPK $\left(\mathrm{N}_{2}\right)$ and recommended NPK + $10 \mathrm{t} \mathrm{ha}^{-1} \mathrm{FYM}\left(\mathrm{N}_{3}\right)$ were applied in kharif rice (var. IET 4786) through consecutive three years (2011-2013). Two lentil varieties viz. Asha (B-77) and Subrata (WBL-58) were sown after rice under zero tillage conditions keeping standing residues and mulch through utilizing residual moisture and nutrients. Zero tillage with straw mulch (ZT-M) in both lentil varieties conserved $12-20 \%$ more water than residue removal (ZT) and $7-10 \%$ more than standing residue $(\mathrm{ZT}-\mathrm{H})$, respectively. During flowering (60 DAS) surface soil $(0-5 \mathrm{~cm})$ of ZT attained $0.8 \mathrm{MPa}$ as compared to 0.2 and 0.1 $\mathrm{MPa}$ for ZT-H and ZT-M, respectively. Soils with $\mathrm{N}_{3}$ stored more water and depleted lesser than $\mathrm{N}_{2}$ and $\mathrm{N}_{1}$ which produced higher biomass, leaf relative water content (RWC) and chlorophyll content. Soil thermal variation in ZT-M tends to proliferate root and nutrient uptake that increased 19 and $14 \%$ more yield and 25 and $15 \%$ more water use efficiency (WUE) than ZT-H and ZT. Both Subrata and Asha performed well under zero tillage conditions. Zero tillage and nutrient management had an effect on soil microbial biomass carbon (SMBC) and dehydrogenase activity as ZT $<\mathrm{ZT}-\mathrm{H}<\mathrm{ZT}-\mathrm{M}$ and $\mathrm{N}_{3}>\mathrm{N}_{2}>\mathrm{N}_{1}$. Proper technology with application of zero tillage may explore the possibility of growing lentil crops in rice fallows during postrainy season utilizing carry-over soil moisture and residual soil fertility.
\end{abstract}

\section{Introduction}

Lentil is an annual, most promising cool season grain legume in India, ranks first in the world in respect of production, accounting for approximately $27 \%$ of the world's production with a national average productivity of $1000 \mathrm{~kg} \mathrm{ha}^{-1}$ under rainfed conditions. In West Bengal, lentil occupies an area of $0.065 \mathrm{~m}$ ha area with a productivity of $763 \mathrm{~kg} \mathrm{ha}^{-1}$ (FAO, 2010), grows under rainfed conditions on residual soil moisture during pre winter (from late November to early December) and faces soil moisture deficit and high temperature at reproductive growth stage (Gupta and Bhowmick, 2005). However, information on actual moisture needs and time and intensity of stress occurs using post-rainy season crops with residual soil moisture in rice fallows are very scarce. If ploughing is done after harvest of rice to remove stubbles, sowing of lentil is delayed which in turn produce water deficit conditions and that leads to abortion of flowers and young pods and prevents seed filling (Lal et al., 1988; Materne and Reddy, 2007). Nevertheless, all physiological processes in plants are directly affected by water availability (Sarker et al., 2005). The key objective is to tap residual soil moisture and leftover fertility of previous crop by the succeeding lentil crop. If balanced fertilization is done 
Bandyopadhyay et al.

in rainfed puddled rice and crop residues are retained on the soil surface in combination with suitable planting techniques of lentil, it may alleviate terminal drought condition in crops by conserving soil moisture and bring overall improvement in resource management (Ghosh et al., 2010).

No till or zero tillage is an important component of conservation agriculture to produce crops at low cost with profound effect on natural resources such as water and soil (Gangwar et al., 2006). This system is very effective in minimizing soil and crop residue disturbance, controlling soil evaporation, minimizing erosion losses, sequestering carbon in soil and reducing energy needs (Kumar et al., 2011). Therefore, in the present study, the objective was to evaluate the effect of balanced fertilization in puddled rice on moisture storage, stress, microbial diversity and productivity of lentil in rice-fallow cultivated under zero tillage with residue management.

\section{Materials and methods}

\section{Experimental site and treatments imposed}

Field experiments were conducted in 2011-12 to 2013-14 in rice fallow area after short duration (120 days) kharif rice (var. IET 4786) with lentil (var. B-77, Asha and WBL-58, Subrata) under zero tillage in Nadia district of West Bengal $\left(22.99^{\circ} \mathrm{N}, 88.43^{\circ} \mathrm{E}, 13 \mathrm{~m} \mathrm{msl}\right)$. The climate is hot, humid subtropics with an average annual rainfall of approximately 1470 $\mathrm{mm}$ and mean annual minimum and maximum temperatures of 18 and $35 \stackrel{\circ}{ } \mathrm{C}$, respectively. On average, $35 \mathrm{~mm}$ scattered rainfall occurs during November to March and 11 to $25{ }^{\circ} \mathrm{C}$ temperatures (min. and max.) and 50-57\% $\mathrm{RH}$ prevail at the pick growth period (Table 1). The soil is hyperthermic (Aeric Haplaquept, US Soil Taxonomy, Soil Survey Staff, 2003) and clay loam in texture (Table 2), neutral in $\mathrm{pH}$, medium to high in bulk density with low organic matter contents. Three different nutrient managements were applied for rice- i) Farmers' practice $\left(\mathrm{N}_{1}, 40: 20: 20\right.$ as $\left.\mathrm{N}: \mathrm{P}_{2} \mathrm{O}_{5} \mathrm{~K}_{2} \mathrm{O}\right)$, ii) Recommended dose of $\mathrm{N}: \mathrm{P}_{2} \mathrm{O}_{5}: \mathrm{K}_{2} \mathrm{O}=80: 40: 40$ $\left(\mathrm{N}_{2}\right)$ and iii) Recommended dose of $\mathrm{N}: \mathrm{P}_{2} \mathrm{O}_{5}: \mathrm{K}_{2} \mathrm{O}=80: 40: 40+10 \mathrm{t} \mathrm{ha}^{-1} \mathrm{FYM}\left(\mathrm{N}_{3}\right)$, respectively. The rice crop was transplanted on $21^{\text {st }}$ July with seedling age 21 days in rows and was harvested on $1^{\text {st }}$ week of November in 2011, 2012 and 2013, respectively. Seven days after harvesting of rice, the land was used for lentil cultivation under zero tillage system. No fertilizer was applied for lentil, however, $2 \%$ DAP was sprayed at vegetative stage (30 days old). The experiment was laid out in factorial strip plot design with three residue management labels and three replications with the individual plot size being $5 \mathrm{~m} \times 4$ $\mathrm{m}$. Three residue management under zero tillage assigned were:

(i) Zero tillage with residue removal (ZT): seeds were sown @ $30 \mathrm{~kg} \mathrm{ha}^{-1}$ by drilling 65 $\mathrm{mm}$ with hand hoe in between two rice stubbles $(6-8 \mathrm{~cm}$ height) of equal spacing.

(ii) Zero tillage with tall stubble residue $(\mathrm{ZT}-\mathrm{H})$ : seeds were sown @ $30 \mathrm{~kg} \mathrm{ha}^{-1}$ by drilling $65 \mathrm{~mm}$ with hand hoe in between two rice stubbles $(20 \mathrm{~cm}$ height) of equal spacing.

(iii) Zero tillage with residue removal but straw mulching (ZT-M): seeds were sown @ 30 $\mathrm{kg} \mathrm{ha}^{-1}$ by drilling $65 \mathrm{~mm}$ with hand hoe in between two rice stubbles $(6-8 \mathrm{~cm}$ height) of equal spacing then application of surface straw mulch to cover the land.

Stubble cutting height of $6-8$ and $20 \mathrm{~cm}$ stubble left 0.20 and $0.35 \mathrm{~kg} \mathrm{~m}^{-2}\left(\sim 2.0\right.$ and $\left.3.5 \mathrm{t} \mathrm{ha}^{-1}\right)$ residue that retained in the lentil field under $\mathrm{ZT}$ and $\mathrm{ZT}-\mathrm{H}$ systems. On the other hand, 0.45 $\mathrm{kg} \mathrm{m}^{-2}\left(\sim 4.5 \mathrm{t} \mathrm{ha}^{-1}\right)$ rice straw mulch was applied (ZT-M) on $0.20 \mathrm{~kg} \mathrm{~m}^{-2}\left(\sim 2.0 \mathrm{t} \mathrm{ha}^{-1}\right)$ residue left by normal cutting height $(6-8 \mathrm{~cm})$. 
Effect of Balanced Fertilization in Puddled Rice on the Productivity of Lentil

Table 1. Meteorological parameters during rice-lentil cropping system (pooled data of 20112012 to 2013-2014)

\begin{tabular}{l|cc|c|c|c|c}
\hline \multirow{2}{*}{ Month } & \multicolumn{2}{|c|}{$\begin{array}{c}\text { Temperature } \\
\left({ }^{\circ} \mathrm{C}\right)\end{array}$} & \multirow{2}{*}{$\begin{array}{c}\text { Rainfall } \\
(\mathrm{mm})\end{array}$} & $\mathrm{RH}(\%)$ & $\begin{array}{c}\text { Evapo-transpiration } \\
\text { rate }\left(\mathrm{mm} \mathrm{d}^{-1}\right)\end{array}$ & $\begin{array}{c}\text { Bright sunshine } \\
\text { hour }\end{array}$ \\
\cline { 2 - 3 } & Max & Min & & & 2.4 & 4.8 \\
July & 32.7 & 26.4 & 198.7 & 79.6 & 2.1 & 4.3 \\
August & 32.0 & 26.2 & 388.2 & 81.5 & 2.2 & 6.0 \\
September & 32.8 & 25.9 & 268.5 & 77.7 & 2.2 & 7.3 \\
October & 32.6 & 23.5 & 112.8 & 66.7 & 1.5 & 5.9 \\
November & 29.8 & 17.3 & 9.4 & 55.7 & 1.0 & 5.6 \\
December & 25.9 & 12.5 & 2.4 & 58.4 & 1.1 & 6.2 \\
January & 24.2 & 11.1 & 2.5 & 57.4 & 1.5 & 8.2 \\
February & 28.8 & 12.7 & 9.5 & 50.3 & 2.7 & \\
March & 32.8 & 17.5 & 10.9 & 47.1 & & \\
\hline
\end{tabular}

Table 2. Physical properties of soil of the experimental soils

\begin{tabular}{|c|c|c|c|c|c|c|}
\hline \multirow{2}{*}{ Soil Properties } & \multicolumn{6}{|c|}{ Soil depth (cm) } \\
\hline & $0-5$ & $5-10$ & $10-20$ & $20-30$ & $30-40$ & $40-60$ \\
\hline Sand (\%) & 35 & 35 & 33 & 35 & 31 & 38 \\
\hline Silt (\%) & 28 & 28 & 29 & 27 & 27 & 26 \\
\hline Clay (\%) & 37 & 37 & 38 & 38 & 42 & 36 \\
\hline Textural class & \multicolumn{6}{|c|}{ Clay loam } \\
\hline Bulk density $\left(\mathrm{g} \mathrm{cm}^{-3}\right)$ & 1.42 & 1.51 & 1.60 & 1.65 & 1.70 & 1.73 \\
\hline WHC (\%) & 68 & 67 & 64 & 62 & 60 & 60 \\
\hline $\begin{array}{l}\text { Saturated hydraulic } \\
\text { conductivity }\left(\mathrm{cm} \mathrm{h}^{-1}\right)\end{array}$ & 0.12 & 0.12 & 0.07 & 0.03 & 0.01 & 0.01 \\
\hline $\begin{array}{l}\text { Soil moisture content } \\
\text { (\%) at FC and WP }\end{array}$ & 34,15 & 34,15 & 31,12 & 28,12 & 28,12 & 28,12 \\
\hline
\end{tabular}

\section{Soil moisture studies}

Soil moisture measurement was done by using core sampler of $4 \mathrm{~cm}$ in diameter and a length of $3 \mathrm{~cm}$ for the surface soil $(0-5 \mathrm{~cm})$ and by a PR2/6 Profile Probe soil moisture meter for 5-10, 10-20, 20-30, 30-40 and 40-60 cm depths at 7 days interval in three years. The periodic stress coefficient $K_{s}$ was determined as stated by Allen et al. (1998) using soil moisture depletion study. The actual water use (AWU) throughout the growing season of lentil was computed using the water balance relationship as:

$$
\mathbf{A W U}=\mathbf{D}_{\mathbf{r}}+\mathbf{P}
$$

where, $D_{r}=$ soil moisture depletion in the root zone $(40 \mathrm{~cm})$ from sowing to the end of the season $(\mathrm{mm}) ; \mathrm{P}=$ effective precipitation in the crop growth season $(\mathrm{mm})$, collected from the nearby meteorological observatory.

\section{Plant parameters}

The relative water content (RWC) of leaves was estimated at vegetative [30 days after sowing (DAS), flowering (60 DAS) and pod formation (90 DAS) stages by the method of Barrs and Weatherly (1962) by using the following equation: 
Bandyopadhyay et al.

$$
\mathrm{RWC}=\frac{\mathrm{FW}-\mathrm{DW}}{\mathrm{TW}-\mathrm{DW}} \times 100
$$

Where, $\mathrm{TW}=$ turgid weight, $\mathrm{DW}=$ dry weight and $\mathrm{FW}=$ fresh weight of leaves. Maximum above ground dry biomass was measured at vegetative, flowering and at pod formation stages.

\section{Yield and water use efficiency}

The lentil crops were harvested manually by uprooting at grain maturity stage $(15 \%$ moisture content) on the second week of March. The water use efficiency (WUE, $\mathrm{kg} \mathrm{ha}^{-1} \mathrm{~mm}^{-1}$ ) was calculated using lentil seed yield in relation to actual water used from sowing to harvesting as:

WUE $=\frac{\text { FLentil seedyield }}{\text { Total water used }}$

All statistical analyses were performed using IBM, SPSS v. 20.0 (SPSS Inc. Chicago, IL, USA) for windows. Nutrients and residue effects on measured variables were performed by analysis of variance (ANOVA) through the general linear model (GLM) using factorial strip plot design.

\section{Results and discussion}

\section{Soil moisture dynamics}

Temporal soil moisture distribution throughout the profile indicated a decrease in trend from sowing to harvesting under different residues and nutrient management practices (Fig. 1). No significant variations of spatial and temporal moisture content were observed in plots with Asha (B-77) and Subrata (WBL-58). Results showed that treatments with ZT-M dried slower than $\mathrm{ZT}-\mathrm{H}$ and $\mathrm{ZT}$, respectively, however, no significant variations were observed under residual effect of nutrient management in rice. The rate of diminution soil moisture with time was more in surface $(0-5 \mathrm{~cm})$ soils of ZT compared to ZT-H and ZT-M (Fig. 1) indicating more evaporation loss as the exposed soil is venerable to evaporation (Kar and Kumar, 2009). During initiation of flowering the depletion was observed more in ZT and less in ZT-M; more in $\mathrm{N}_{1}$ as compared to $\mathrm{N}_{2}$ and $\mathrm{N}_{3}$ treatments, however, no differences among Asha and Subrata in tillage and nutrients management was observed.

The distribution of moisture content of $1 \mathrm{~m}$ profile with depth and time during the lentil growth period (Fig. 1) shows that at any suction value, the volumetric moisture retention is the lowest at the surface and is the highest at the bottom most layer of the soil profile. It was also evidenced that a hydraulic gradient existed upward in the root zone indicating an upward capillary flux might have occurred from deeper soil layers. However, a reduction in soil moisture at $20-30 \mathrm{~cm}$ layer forming neckline (Fig. 1), signifies mechanical impediment that might restricts upward contribution. The critical soil moisture, worked out from water availability decreased with increasing depth with a mean value of $22 \%$.

At surface soil $(0-5 \mathrm{~cm})$, zero tillage with straw mulch (ZT-M) conserved $3-8 \%$ higher amount of moisture as compared to zero tillage with residue (ZT-H) or without (ZT) (data not shown). There was a sharp fall in soil moisture storage from vegetative to pod formation stages (Table 3). Zero tillage controls the stored soil moisture significantly at the trend of ZT-M > $\mathrm{ZT}-\mathrm{H}>\mathrm{ZT}$. Residue with ZT-M and ZT-H stored $12-20 \%$ and $4-13 \%$ more water than $\mathrm{ZT}$. Nonetheless, ZT-M stored $7-10 \%$ more than $\mathrm{ZT}-\mathrm{H}$, respectively. Favourable hydrothermal 


\section{Effect of Balanced Fertilization in Puddled Rice on the Productivity of Lentil}

regime due to mulching encouraged root growth and thus enhanced utilization of conserved soil moisture by rainfed crops (Acharya and Sharma, 1994). Soil fertility levels also modified soil moisture storage significantly as $N_{3}>N_{2}>N_{1}$ where $N_{3}$ and $N_{2}$ stored $9-16 \%$ and $4-13 \%$ more moisture than $N_{1}$. Soils under variety Asha (B-77) stored significantly higher soil moisture (6-11\%) as compared to Subrata (WBL-58). The actual water used by lentil crop in the root zone $(0-40 \mathrm{~cm})$ was significantly affected by zero tillage where ZT $>\mathrm{ZT}-\mathrm{H}>\mathrm{ZT}-\mathrm{M}$, amounting 19.5, 18.8 and $18.7 \mathrm{~cm}$, respectively (Table 4). On average, $19.0 \mathrm{~cm}$ water was actually used by lentil crop under zero tillage systems. The finding is in close agreement with $18.5 \mathrm{~cm}$ (Tuti et al., 2012) in humid tropical and sub-tropical climate. Lower profile water change (depletion) under lentil in ZT-M was due to less or no evaporation from soil surface throughout the growing period as compared to $\mathrm{ZT}-\mathrm{H}$ and $\mathrm{ZT}$, respectively (Table 4). The lentil crop received $12.9 \mathrm{~mm}$ mean effective precipitation during the cropping seasons. An artificial barrier with straw and standing stubbles may help for slow and steady entry of water and thus may reduce drainage loss. Nutrient management in rice also significantly affected the actual water use as $N_{1}>N_{2}>N_{3}$ indicating the effect of continuous application of FYM on soil moisture dynamics.
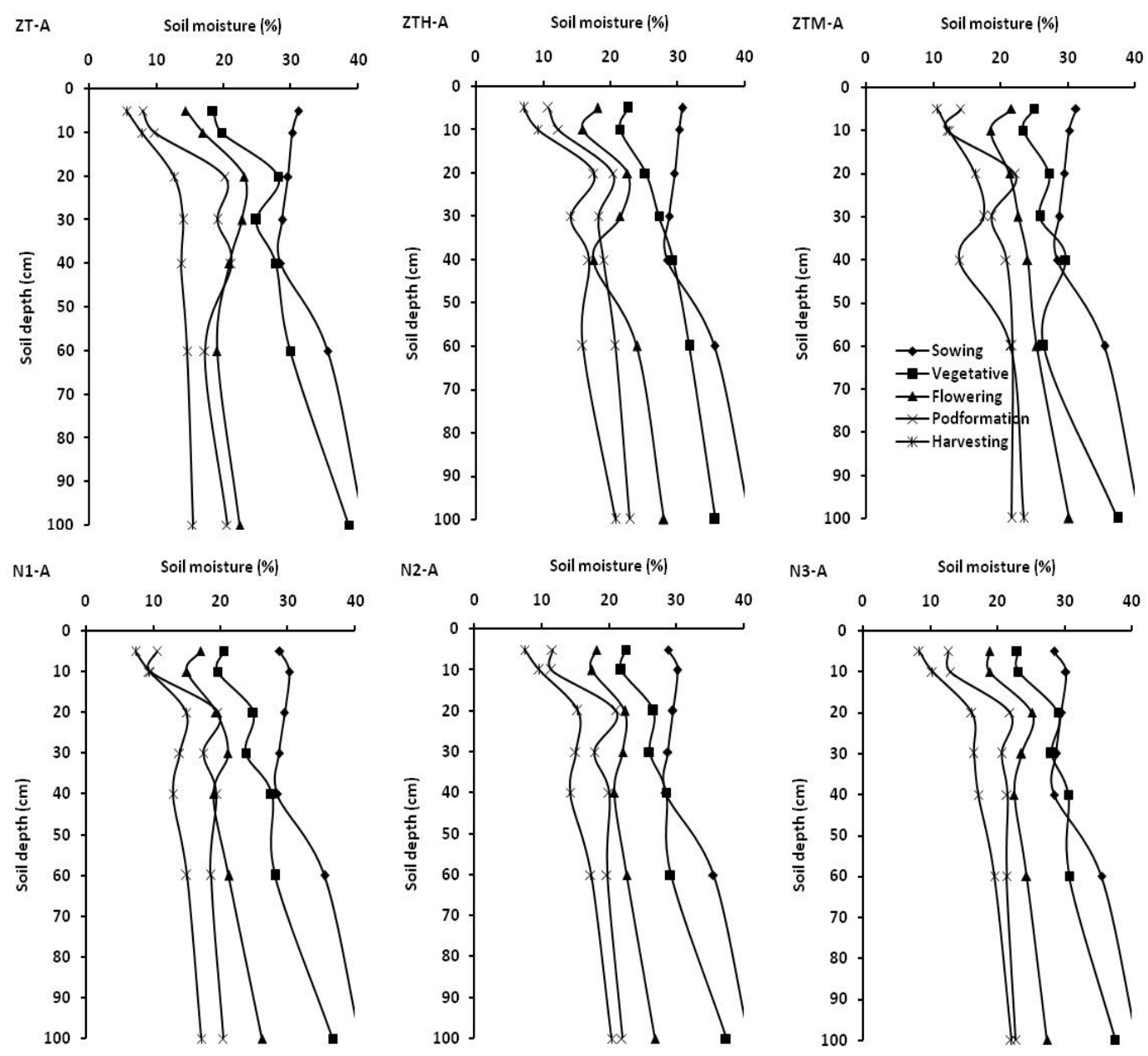
Bandyopadhyay et al.

Fig. 1. Distribution of moisture within soil profile at critical growth periods under different nutrient and residue management practices (pooled data of three years with var. Asha)

Table 3. Soil moisture storage $(\mathrm{cm})$ at critical stages under different nutrient and residue management practices

\begin{tabular}{|c|c|c|c|c|c|c|c|c|c|}
\hline \multirow{2}{*}{ Residue } & \multicolumn{3}{|c|}{ Asha } & \multicolumn{3}{|c|}{ Subrata } & \multicolumn{3}{|c|}{ Mean } \\
\hline & $\mathrm{V}$ & $\mathrm{F}$ & $\mathrm{Pf}$ & $\mathrm{V}$ & $\mathrm{F}$ & $\mathrm{Pf}$ & $\mathrm{V}$ & $\mathrm{F}$ & $\mathrm{Pf}$ \\
\hline ZT & 8.79 & 7.43 & 5.78 & 8.12 & 6.68 & 4.65 & 8.46 & 7.05 & 5.21 \\
\hline $\mathrm{ZT}-\mathrm{H}$ & 9.50 & 7.61 & 6.28 & 8.38 & 7.02 & 5.72 & 8.94 & 7.32 & 6.00 \\
\hline ZT-M & 9.70 & 8.11 & 6.69 & 9.53 & 8.06 & 6.40 & 9.61 & 8.08 & 6.54 \\
\hline Mean & 9.33 & 7.72 & 6.25 & 8.68 & 7.25 & 5.59 & 9.00 & 7.48 & 5.92 \\
\hline Nutrient & $\mathrm{V}$ & $\mathrm{F}$ & $\mathrm{Pf}$ & $\mathrm{V}$ & $\mathrm{F}$ & $\mathrm{Pf}$ & $\mathrm{V}$ & $\mathrm{F}$ & $\mathrm{Pf}$ \\
\hline $\mathrm{N}_{1}$ & 8.83 & 7.08 & 5.91 & 8.21 & 6.36 & 5.38 & 8.52 & 6.72 & 5.64 \\
\hline $\mathrm{N}_{2}$ & 9.23 & 7.76 & 6.15 & 8.49 & 7.40 & 5.63 & 8.86 & 7.58 & 5.89 \\
\hline $\mathrm{N}_{3}$ & 9.93 & 8.31 & 6.69 & 9.33 & 8.00 & 5.76 & 9.63 & 8.16 & 6.23 \\
\hline Mean & 9.33 & 7.72 & 6.25 & 8.68 & 7.25 & 5.59 & 9.00 & 7.48 & 5.92 \\
\hline Source & LSD (0.05) & & & & & & & & \\
\hline Nutrient & 0.217 & & & & & & & & \\
\hline Residue & 0.238 & & & & & & & & \\
\hline Variety & 0.145 & & & & & & & & \\
\hline Stage & 0.258 & & & & & & & & \\
\hline Residue*Var & 1.234 & & & & & & & & \\
\hline
\end{tabular}

$\mathrm{N}_{1}=40: 20: 20$ as $\mathrm{N}: \mathrm{P}_{2} \mathrm{O}_{5}: \mathrm{K}_{2} \mathrm{O}, \mathrm{N}_{2}=$ recommended $\mathrm{N}: \mathrm{P}_{2} \mathrm{O}_{5}: \mathrm{K}_{2} \mathrm{O}=80: 40: 40, \mathrm{~N}_{3}=\mathrm{N}_{2}+10$ t ha $^{-1} \mathrm{FYM}$, $\mathrm{FYM}=$ Farmyard manure, $\mathrm{ZT}=$ Zero tillage with residue removal, $\mathrm{ZT}-\mathrm{H}=$ Zero tillage with tall stubble height, $\mathrm{ZT}-\mathrm{M}=$ Zero tillage with residue removal but with straw mulch, $\mathrm{V}=$ Vegetative stage, $\mathrm{F}=$ Flowering stage, $\mathrm{Pf}=\mathrm{Pod}$ Formation stage.

Table 4. Total water used of lentils $(\mathrm{cm})$ under different nutrient and residue management practices

\begin{tabular}{|c|c|c|c|c|c|c|c|c|c|}
\hline \multirow{2}{*}{ Residue/ Tillage } & \multicolumn{3}{|c|}{ Asha } & \multicolumn{3}{|c|}{ Subrata } & \multicolumn{3}{|c|}{ Mean } \\
\hline & $\mathrm{D}(\mathrm{cm})$ & $\mathrm{P}(\mathrm{cm})$ & $\mathrm{W}(\mathrm{cm})$ & $\mathrm{D}(\mathrm{cm})$ & $\mathrm{P}(\mathrm{cm})$ & $\mathrm{W}(\mathrm{cm})$ & $\mathrm{D}(\mathrm{cm})$ & $\mathrm{P}(\mathrm{cm})$ & $\mathrm{W}(\mathrm{cm})$ \\
\hline ZT & 6.90 & 12.90 & 19.70 & 6.40 & 12.90 & 19.20 & 6.65 & 12.90 & 19.45 \\
\hline ZT-H & 5.90 & 12.90 & 18.80 & 6.00 & 12.90 & 18.90 & 5.95 & 12.90 & 18.85 \\
\hline ZT-M & 5.70 & 12.90 & 18.60 & 6.00 & 12.90 & 18.90 & 5.85 & 12.90 & 18.75 \\
\hline Mean & 6.17 & 12.90 & 19.03 & 6.13 & 12.90 & 19.00 & 6.15 & 12.90 & 19.02 \\
\hline Nutrient & $\mathrm{D}(\mathrm{cm})$ & $\mathrm{P}(\mathrm{cm})$ & $\mathrm{W}(\mathrm{cm})$ & $\mathrm{D}(\mathrm{cm})$ & $\mathrm{P}(\mathrm{cm})$ & $\mathrm{W}(\mathrm{cm})$ & $\mathrm{D}(\mathrm{cm})$ & $\mathrm{P}(\mathrm{cm})$ & $\mathrm{W}(\mathrm{cm})$ \\
\hline $\mathrm{N}_{1}$ & 6.58 & 12.90 & 19.40 & 6.77 & 12.90 & 19.60 & 6.68 & 12.90 & 19.50 \\
\hline $\mathrm{N}_{2}$ & 6.28 & 12.90 & 19.10 & 6.17 & 12.90 & 19.10 & 6.23 & 12.90 & 19.10 \\
\hline $\mathrm{N}_{3}$ & 5.65 & 12.90 & 18.60 & 5.46 & 12.90 & 18.30 & 5.56 & 12.90 & 18.45 \\
\hline Mean & 6.17 & 12.90 & 19.03 & 6.13 & 12.90 & 19.00 & 6.15 & 12.90 & 19.02 \\
\hline Source & LSD (0.05) & & & & & & & & \\
\hline Nutrient & 0.277 & & & & & & & & \\
\hline Residue & 0.338 & & & & & & & & \\
\hline Residue ${ }^{*}$ Variety & 3.086 & & & & & & & & \\
\hline
\end{tabular}

$\mathrm{N}_{1}=40: 20: 20$ as $\mathrm{N}: \mathrm{P}_{2} \mathrm{O}_{5}: \mathrm{K}_{2} \mathrm{O}, \mathrm{N}_{2}=$ recommended $\mathrm{N}: \mathrm{P}_{2} \mathrm{O}_{5}: \mathrm{K}_{2} \mathrm{O}=80: 40: 40, \mathrm{~N}_{3}=\mathrm{N}_{2}+10$ tha $^{-1} \mathrm{FYM}$, $\mathrm{FYM}=$ Farmyard manure, $\mathrm{ZT}=$ Zero tillage with residue removal, $\mathrm{ZT}-\mathrm{H}=$ Zero tillage with tall stubble 
height, $\mathrm{ZT}-\mathrm{M}=$ Zero tillage with residue removal but with straw mulch, $\mathrm{D}=$ Depletion, $\mathrm{P}=$ Precipitation, $\mathrm{W}=$ Water used.

\section{Plant growth parameters}

Leaf relative water content (RWC) is of the best growth/biochemical indices revealing the stress intensity (Alizade, 2002). The RWC increased from vegetative to pod formation stages under all the treatments (Fig. 2). The RWC ranged from $62-65 \%$ during vegetative to $72-78 \%$ during flowering to $75-87 \%$ at pod formation stage for residue and nutrient management practices and it was significantly $(\mathrm{P}<0.05)$ higher in $\mathrm{ZT}-\mathrm{H}$ and $\mathrm{ZT}-\mathrm{M}$ throughout the growth period as compared to ZT. At pod formation stage, ZT-H and ZT-M treatments significantly $(P<0.05)$ increased $12-15 \%$ higher RWC than ZT. On the other hand, RWC in $N_{3}$ and $N_{2}$ were $2-7 \%$ higher than $N_{1}$. Results thus indicated that where there were more moisture (plots with applied mulch and residue retention), the plants were turgid and succulent producing higher RWC compared to residue removal with low amount of moisture (Fig. 2). Both varieties had no significant effect on RWC at different growth periods.
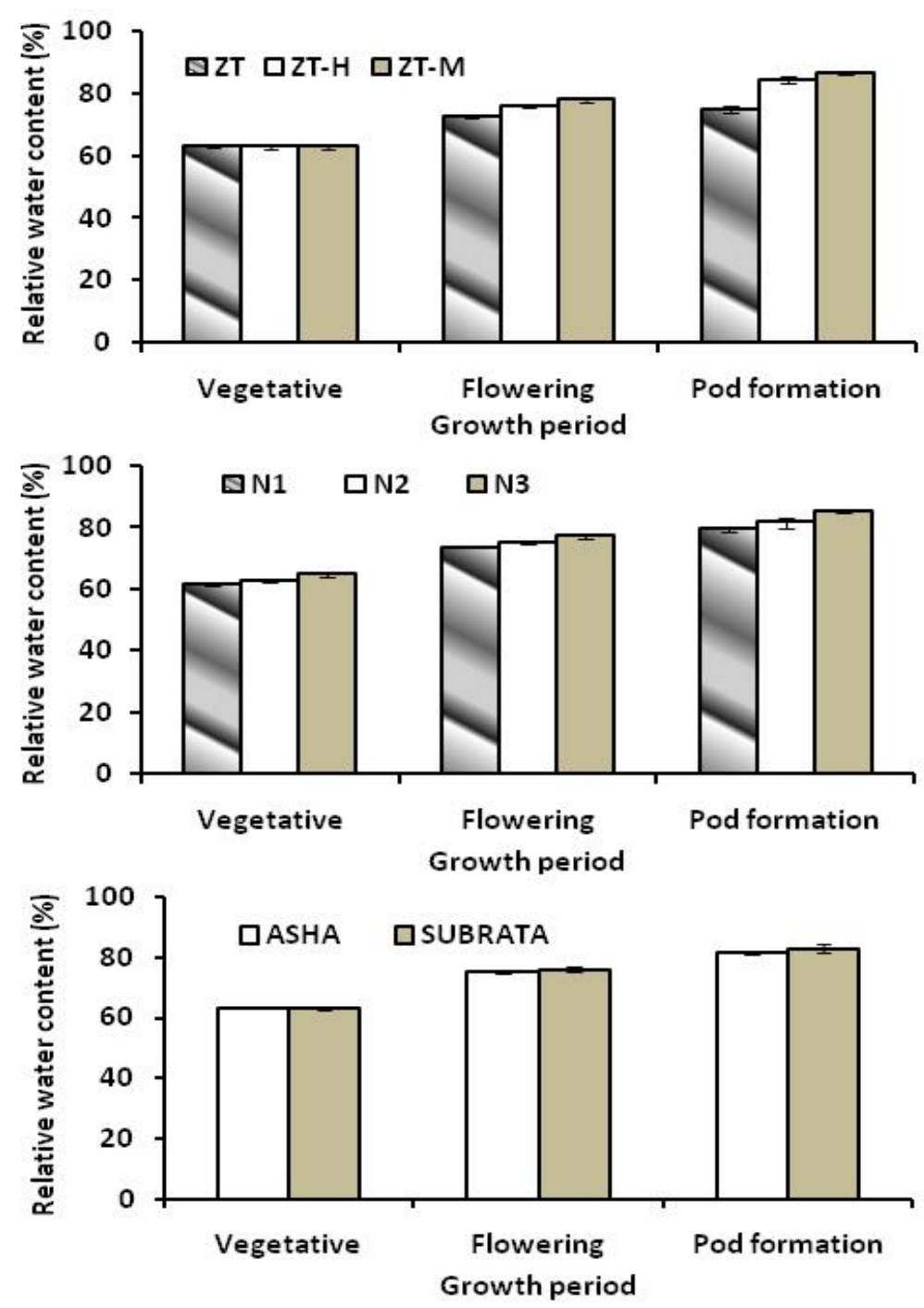
Bandyopadhyay et al.

Fig. 2. Relative water content under different nutrient and residue management practices

Zero tillage with straw mulching had maximum dry biomass compared to $\mathrm{ZT}-\mathrm{H}$ and $\mathrm{ZT}$ treatments at flowering and pod formation stages (Fig. 3). ZT-H and ZT-M produced 21 and $63 \%$ higher biomass as compared to ZT, and ZT-M produced $35 \%$ higher biomass than ZT$\mathrm{H}$. On the other hand, $\mathrm{N}_{3}$ had $41 \%$ higher biomass than $\mathrm{N}_{2}$ and $57 \%$ higher than $\mathrm{N}_{1}$, respectively (Fig. 3). Asha (B-77) produced only 6\% higher biomass than Subrata (WBL-58). Root:shoot ratio decreased with the advancement of crop growth (Fig. 4) indicating less root proliferation in zero tillage condition. ZT produced higher root-shoot compared to $\mathrm{ZT}-\mathrm{H}$ and ZT-M may be due to increase of root system in cracks developed under moisture stress (Bandyopadhyay, 2014).
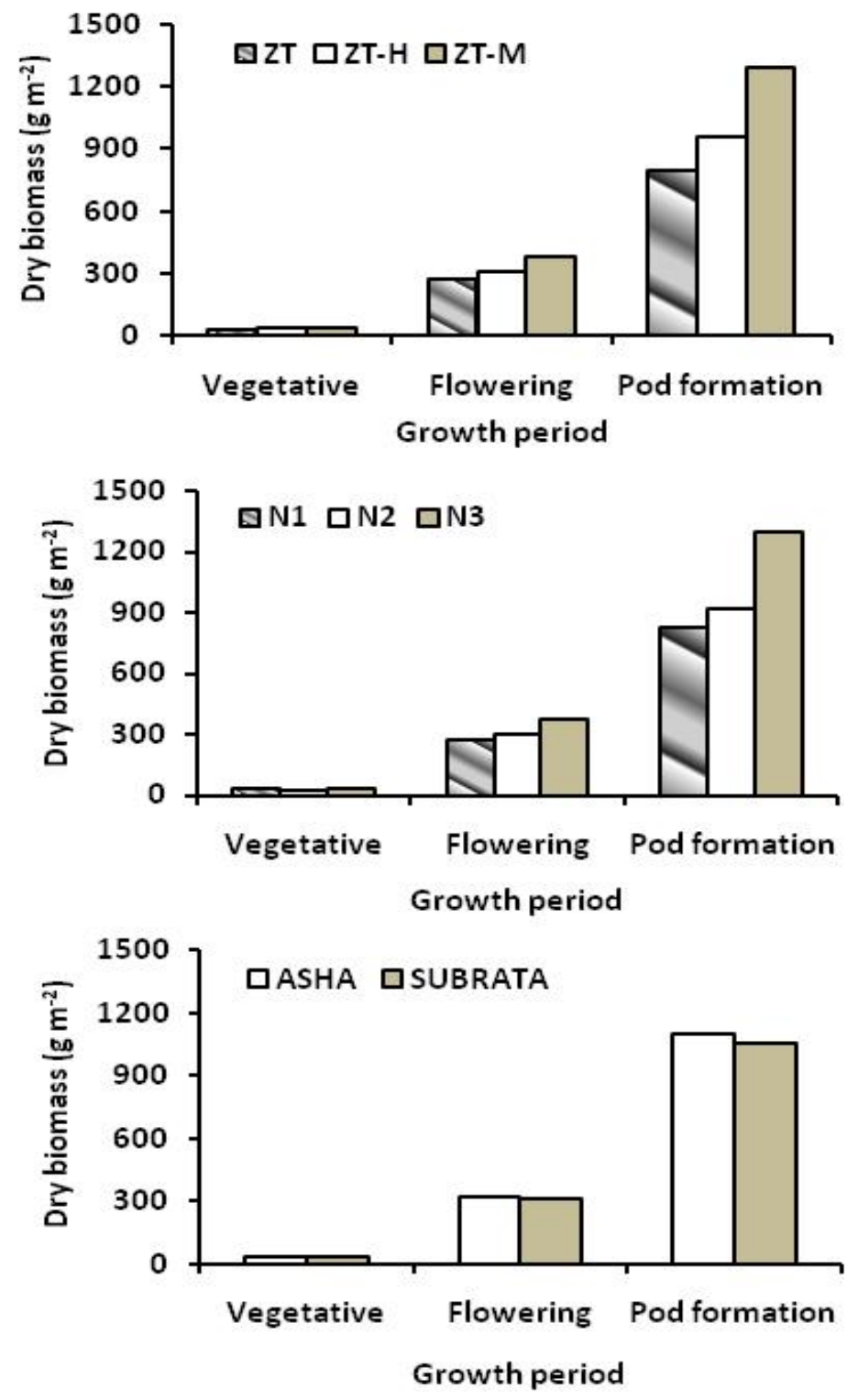

Fig. 3. Dry biomass under different nutrient and residue management practices 


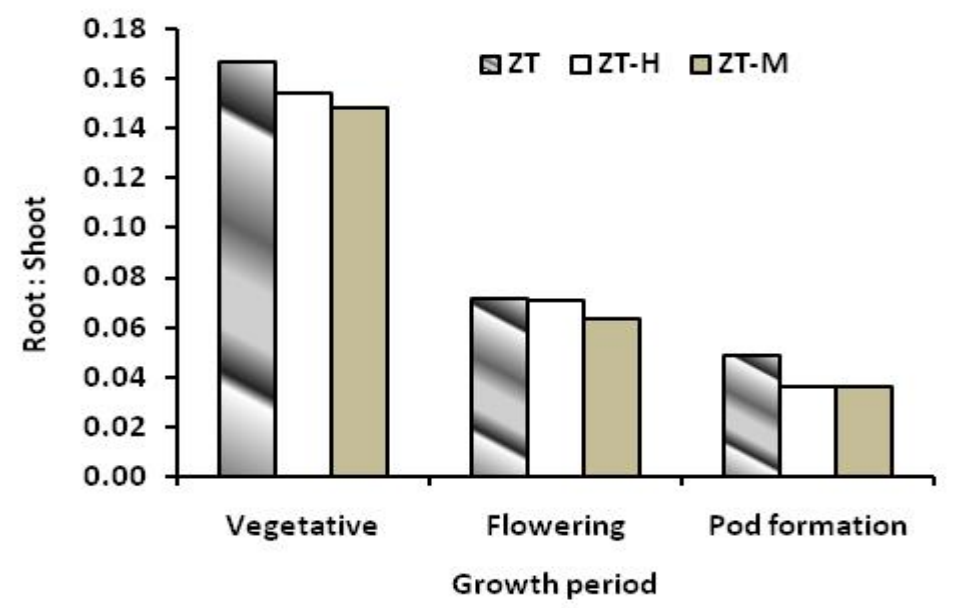

Fig. 4. Root: shoot ratio under different nutrient and residue management practices
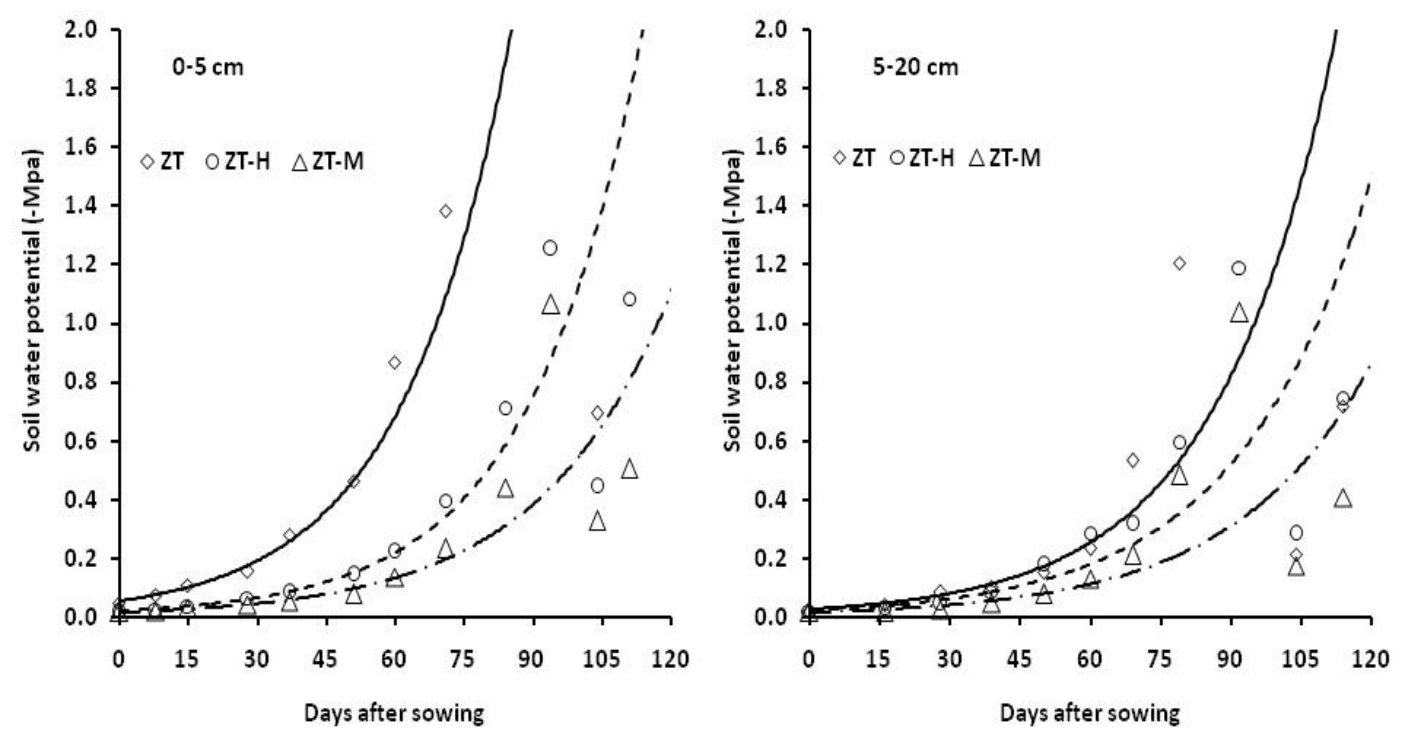

Fig. 5. Soil drying out pattern under zero tillage (ZT) with stubble height (ZT-H) and with mulch (ZT-M)

\section{Soil Properties}

Soil drying pattern of ZT-M was slower than ZT-H and ZT at surface $(0-5 \mathrm{~cm})$ and subsurface $(5-20 \mathrm{~cm})$ soil layers (Fig. 5) throughout the growth period. During initiation of flowering (60 DAS) ZT achieved $0.8 \mathrm{MPa}$ tension as compared to 0.2 and $0.1 \mathrm{MPa}$ for ZT-H and ZT-M, respectively. Results thus showed that the drying out pattern during flowering to pod formation stage may be modified by keeping straw mulching (ZT-M) or tall stubble height (ZT-H). The intensity of stress faced by lentil, under zero tillage is depicted in Fig. 6. At the beginning of the growing season (10 DAS), lentil in zero tillage showed the values of $K_{s}=1$, i.e., the soil water deficit was less than the readily available water of the root zone. During flowering stage, lentil with residue removal (ZT) experienced more than $20 \%$ stress 
Bandyopadhyay et al.

and it increased gradually. The diminution of $\mathrm{K}_{\mathrm{s}}$ values may be attributed to the increase in water depletion at the root zone through the removal of water by evapotranspiration that induced stress condition (Bandyopadhyay and Mallick, 2003). The Ks values of the soil to 40 $\mathrm{cm}$ rooting depth reached below a value of 0.5 and 0.8 (Fig. 6) at pod formation stage (100 d) with ZT and ZT-H, however, stress starts in ZT-M after $105 \mathrm{~d}$ when the pod matured. A steep decrease with prolonged lower $K_{s}$ values of $Z T$ indicates a more stressed condition than ZT-H (Fig. 6). Thus, zero tillage reduced the intensity of stress. Zero tillage and nutrient management had an effect on soil microbial biomass carbon (SMBC) and soil dehydrogenase activity (Fig. 7). Mulch treatment (ZT-M) produced more SMBC and dehydrogenase as compared to residue removal (ZT) and low fertility $\left(\mathrm{N}_{1}\right)$. Asha (B-77) and Subrata (WBL-58) had no significant effect on SMBC and dehydrogenase activity.

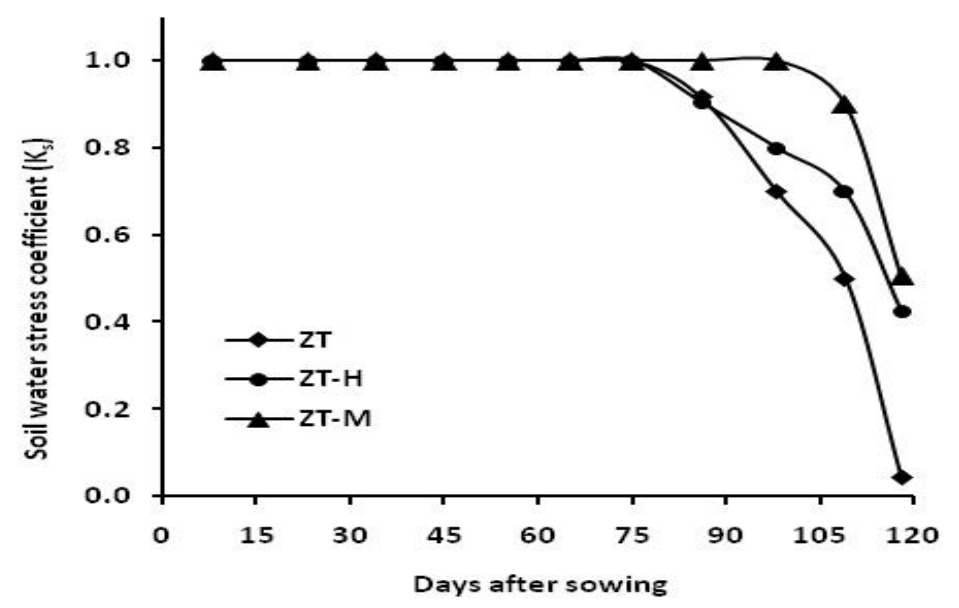

Fig. 6. Soil water stress coefficients under different residue management practices
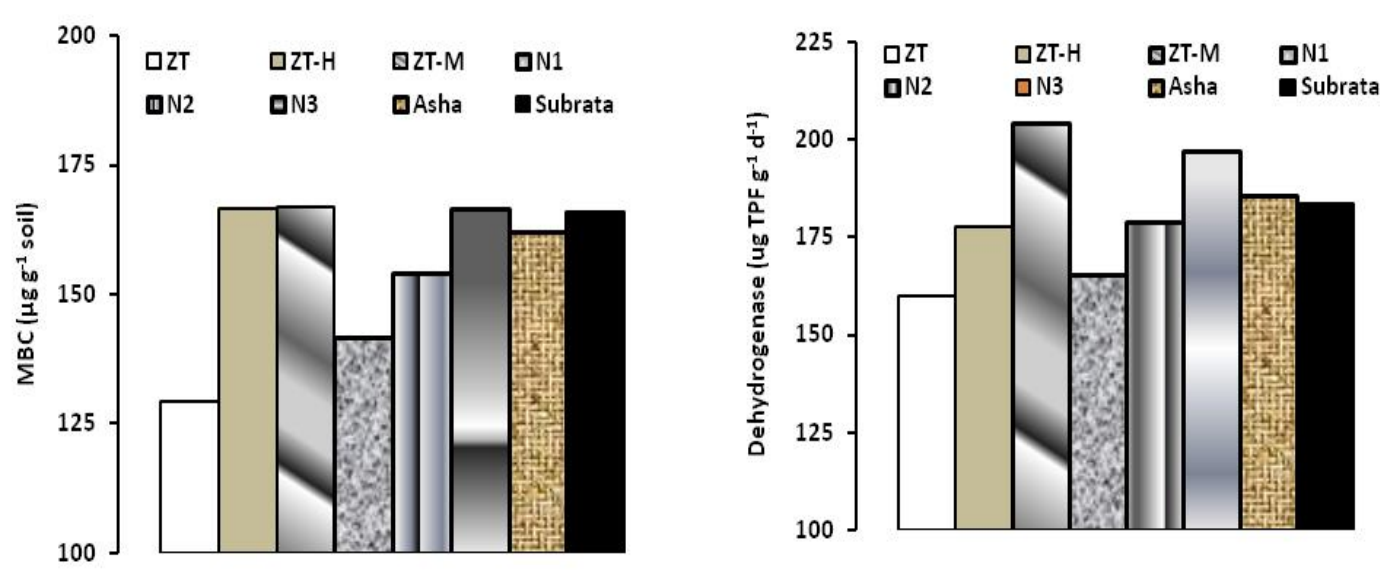

Fig. 7. Microbial biomass $C$ and soil dehydrogenase activity under different nutrient and residue management practices

Yield and water use efficiency 
Effect of Balanced Fertilization in Puddled Rice on the Productivity of Lentil

Pooled data of yield for three years indicated that the yield was significantly affected by zero tillage and nutrient management as ZT-M $>\mathrm{ZT}-\mathrm{H}>\mathrm{ZT}$ and $\mathrm{N}_{3}>\mathrm{N}_{2}>\mathrm{N}_{1}$ (Table 5). ZT-M (22.1 $\mathrm{q} \mathrm{ha}^{-1}$ ) produced 19.0 and $14.5 \%$ more yield than ZT $\left(17.9 \mathrm{q} \mathrm{ha}^{-1}\right) \mathrm{ZT}-\mathrm{H}\left(18.9 \mathrm{q} \mathrm{ha} \mathrm{h}^{-1}\right)$. $\mathrm{N}_{3}\left(20.9 \mathrm{q} \mathrm{ha}^{-1}\right.$ ) produced 7 to $11 \%$ more than $\mathrm{N}_{2}$ and $\mathrm{N}_{1}$, respectively. There was no significant variation in yield between variety (19.2 and $\left.20.1 \mathrm{q} \mathrm{ha} \mathrm{h}^{-1}\right)$. Tripathi and Singh (1987), Singh and Verma (1996) in north India found the highest yield of 22.9 and $18.4 \mathrm{q} \mathrm{ha}^{-1}$ using different varieties. ZT-M significantly produced 15 and $25 \%$ higher water use efficiency (WUE) as compared to ZT-H (21.7 kg ha $\left.\mathrm{mm}^{-1}\right)$ and ZT $\left(19.1 \mathrm{~kg} \mathrm{ha}^{-1} \mathrm{~mm}^{-1}\right)$. Nutrient management with $\mathrm{N}_{3}$ improved WUE @14 to $21 \%$ as compared to $\mathrm{N}_{2}$ and $\mathrm{N}_{1}$. The achieved WUE values of lentil in our study were within the range as described by Singh et al. (2010). Zero tillage with straw mulching modified soil temperature and kept minimal diurnal variation which tends to proliferate root and nutrient uptake that increased yield and WUE.

Table 5. Seed yield of lentil under different nutrient and residue management practices

\begin{tabular}{|c|c|c|c|c|c|c|c|c|c|c|c|c|c|c|c|c|}
\hline \multirow{2}{*}{$\begin{array}{c}\text { Variety/ } \\
\text { Treatment }\end{array}$} & \multicolumn{4}{|c|}{$\mathrm{N}_{1}$} & \multicolumn{4}{|c|}{$\mathrm{N}_{2}$} & \multicolumn{4}{|c|}{$\mathrm{N}_{3}$} & \multicolumn{4}{|c|}{ Overall } \\
\hline & ZT & ZT-H & $\begin{array}{c}\text { ZT- } \\
M\end{array}$ & Mean & ZT & \begin{tabular}{|c|} 
ZT- \\
$\mathrm{H}$
\end{tabular} & \begin{tabular}{|c|} 
ZT- \\
M
\end{tabular} & Mean & ZT & $\begin{array}{c}\text { ZT- } \\
\mathrm{H}\end{array}$ & \begin{tabular}{|c|} 
ZT- \\
M
\end{tabular} & Mean & ZT & $\begin{array}{c}\text { ZT- } \\
\mathrm{H}\end{array}$ & \begin{tabular}{|c|} 
ZT- \\
$M$
\end{tabular} & Mean \\
\hline $\begin{array}{c}\text { Asha } \\
\text { (B-77) } \\
\text { Subrata }\end{array}$ & 16.5 & 17.7 & 20.9 & 18.4 & 17.4 & 18.4 & 21.1 & 19.0 & 17.8 & 19.7 & 23.5 & 20.3 & 17.2 & 18.6 & 21.8 & 19.2 \\
\hline $\begin{array}{c}\text { (WBL- } \\
58)\end{array}$ & 17.5 & 18.4 & 20.7 & 18.9 & 18.5 & 19.2 & 21.6 & 19.8 & 19.9 & 20.1 & 24.6 & 21.5 & 18.7 & 19.2 & 22.3 & 20.1 \\
\hline Mean & 17.0 & 18.1 & 20.8 & 18.6 & 17.9 & 18.8 & 21.4 & 19.4 & 18.9 & 19.9 & 24.1 & 20.9 & 17.9 & 18.9 & 22.1 & 19.6 \\
\hline Source & $\begin{array}{l}\text { LSD } \\
(0.05)\end{array}$ & & & & & & & & & & & & & & & \\
\hline $\begin{array}{l}\text { Nutrient } \\
\text { Residue }\end{array}$ & $\begin{array}{l}1.20 \\
1.56\end{array}$ & & & & & & & & & & & & & & & \\
\hline
\end{tabular}

$\mathrm{N}_{1}=40: 20: 20$ as $\mathrm{N}: \mathrm{P}_{2} \mathrm{O}_{5}: \mathrm{K}_{2} \mathrm{O}, \mathrm{N}_{2}=$ recommended $\mathrm{N}: \mathrm{P}_{2} \mathrm{O}_{5}: \mathrm{K}_{2} \mathrm{O}=80: 40: 40, \mathrm{~N}_{3}=\mathrm{N}_{2}+10$ t ha $^{-1} \mathrm{FYM}$, $\mathrm{FYM}=$ Farmyard manure, $\mathrm{ZT}=$ Zero tillage with residue removal, $\mathrm{ZT}-\mathrm{H}=$ Zero tillage with tall stubble height, ZT-M = Zero tillage with residue removal but with straw mulch.

Table 6. Water use efficiency as affected by different nutrient and residue management practices

\begin{tabular}{|c|c|c|c|c|c|c|c|c|c|c|c|c|c|c|c|c|}
\hline \multirow{2}{*}{$\begin{array}{c}\text { Variety/ } \\
\text { Treatment }\end{array}$} & \multicolumn{4}{|c|}{$\mathrm{N}_{1}$} & \multicolumn{4}{|c|}{$\mathrm{N}_{2}$} & \multicolumn{4}{|c|}{$\mathrm{N}_{3}$} & \multicolumn{4}{|c|}{ Overall } \\
\hline & ZT & $\begin{array}{c}\text { ZT- } \\
\mathrm{H}\end{array}$ & \begin{tabular}{|c|} 
ZT- \\
$M$
\end{tabular} & Mean & ZT & \begin{tabular}{|c|} 
ZT- \\
$\mathrm{H}$ \\
\end{tabular} & \begin{tabular}{|c|} 
ZT- \\
M \\
\end{tabular} & Mean & ZT & \begin{tabular}{|c|} 
ZT- \\
$\mathrm{H}$
\end{tabular} & \begin{tabular}{|c|} 
ZT- \\
M \\
\end{tabular} & Mean & ZT & \begin{tabular}{|c|} 
ZT- \\
$\mathrm{H}$ \\
\end{tabular} & $\begin{array}{l}\text { ZT- } \\
M\end{array}$ & $\begin{array}{c}\text { Mea } \\
n\end{array}$ \\
\hline $\begin{array}{l}\text { Asha } \\
\text { (B-77) }\end{array}$ & 16.1 & 19.6 & 23.2 & 19.6 & 18 & 20.6 & 24 & 20.9 & 19 & 23.6 & 30.2 & 24.3 & 17.7 & 21.3 & 25.8 & 21.6 \\
\hline $\begin{array}{c}\text { Subrata } \\
\text { (WBL-58) }\end{array}$ & 17.2 & 19.6 & 22.3 & 19.7 & 20 & 23 & 23.8 & 22.3 & 24.1 & 24 & 29.7 & 25.9 & 20.4 & 22.2 & 25.3 & 22.6 \\
\hline Mean & 16.7 & 19.6 & 22.8 & 19.7 & 19.0 & 21.8 & 23.9 & 21.6 & 21.6 & 23.8 & 30.0 & 25.1 & 19.1 & 21.7 & 25.5 & 22.1 \\
\hline Source & $\begin{array}{l}\text { LSD } \\
(0.05) \\
\end{array}$ & & & & & & & & & & & & & & & \\
\hline Nutrient & 3.807 & & & & & & & & & & & & & & & \\
\hline Residue & 2.239 & & & & & & & & & & & & & & & \\
\hline
\end{tabular}

$\mathrm{N}_{1}=40: 20: 20$ as $\mathrm{N}: \mathrm{P}_{2} \mathrm{O}_{5}: \mathrm{K}_{2} \mathrm{O}, \mathrm{N}_{2}=$ recommended $\mathrm{N}: \mathrm{P}_{2} \mathrm{O}_{5}: \mathrm{K}_{2} \mathrm{O}=80: 40: 40, \mathrm{~N}_{3}=\mathrm{N}_{2}+10$ t ha $^{-1} \mathrm{FYM}$, $\mathrm{FYM}=$ Farmyard manure, $\mathrm{ZT}=$ Zero tillage with residue removal, $\mathrm{ZT}-\mathrm{H}=$ Zero tillage with tall stubble height, ZT-M = Zero tillage with residue removal but with straw mulch. 
Bandyopadhyay et al.

Zero tillage with straw mulch (ZT-M) in both lentil varieties conserved $12-20 \%$ more water than residue removal (ZT) and $7-10 \%$ more than standing residue $(\mathrm{ZT}-\mathrm{H})$, respectively. Depletion was more in residue removal (ZT), followed by standing residue (ZT-H) and mulch (ZT-M) that could influence soil drying through increasing soil stress and resistance. ZT-M and application of balanced fertilizer with FYM $\left(\mathrm{N}_{3}\right)$ produced higher biomass, RWC and improved soil microbial diversity. Mulch maintained soil temperature and water movement for growth and rooting in zero tillage system that produced 19 and $14 \%$ more yield and 25 and $15 \%$ more WUE than ZT-H and ZT, respectively. Zero tillage reduced the intensity of stress. Both lentil var. Asha (B-77) and Subrata (WBL-58) performed well under zero tillage system in this region. Balanced fertilization in rice cultivation and zero tillage with straw mulching or keeping tall stubbles height may be an efficient use of existing natural resources for mitigating soil moisture stress and could sustain lentil productivity above national average.

\section{Acknowledgements}

The financial support of the National Agricultural Science Fund (NASF), Indian Council of Agricultural Research (ICAR), New Delhi, for conducting the research is thankfully acknowledged.

\section{References}

Acharya, C. L. and P. D. Sharma. 1994. Tillage and mulch effect on soil physical environment, root growth, nutrient uptake and yield of maize and wheat on an Alfisol in north-west India. Soil Till. Res. 32: 291-302.

Alizade., A. 2002. Soil, Water and Plants Relationship. $3^{\text {rd }}$ Ed. Emam Reza University Press, Mashhad, Iran. P. 353.

Allen, R. G., L. S. Pereira, D. Raes and M. Smith. 1998. Crop Evapotranspiration- Guidelines for Computing Crop Water Requirements, Irrigation and Drain, Paper No. 56. FAO, Rome, Italy. p. 300.

Bandyopadhyay, P. K. 2014. Root distribution pattern of pulses in response to water availability. In: Resource Conservation Technology in Pulses. P. K. Ghosh, M. S Narendra Kumar, Venkatesh, K. K. Hazra and N. Nadarajan (eds.). Scientific Publishers, India. Pp. 512520.

Bandyopadhyay, P. K. and S. Mallick. 2003. Actual evapotranspiration and crop coefficients of wheat (Triticum aestivum) under varying moisture levels of humid tropical canal command area. Agric. Water Manage. 59: 33-47.

Barrs, H. D. and P. E. Weatherly. 1962. A re examination of relative turgidity for estimating water deficit in leaves. Aust. J. Biol. Sci. 15: 413-428.

FAO, 2010. FAOSTAT statistical database of the United Nations Food and Agriculture Organization (FAO), Rome, Italy.

Gangwar, K. S., K. K. Singh, S. K. Sharma and O. K. Tomar. 2006. Alternative tillage and crop residue management in wheat after rice in sandy loam soils of Indo-Gangatic plains. Soil Till. Res. 88: 242-252.

Ghosh, P. K., A. Das, R. Saha, K. Enboklang, A. K. Tripathi, G. C. Munda and S. V. Ngachan. 2010. Conservation agriculture towards achieving food security in North East India. Curr. Sci. 99: 915-921. 
Effect of Balanced Fertilization in Puddled Rice on the Productivity of Lentil

Gupta, S. and M. K. Bhowmick. 2005. Scope of growing lathyrus and lentil in relay cropping systems after rice in West Bengal, India. Lathyrus Lathyrism Newsletter. 4: 28-33.

Kar, G. and A. Kumar. 2009. Evaluation of post-rainy season crops with residual soil moisture and different tillage methods in rice fallow of eastern India. Agric. Water Manage. 96: 931-938.

Kumar, S., R. G. Singh, C. Piggin, A. Haddad, S. Ahmed and Raj Kumar. 2011. No-till lentil: An option for profitable harvest in dry areas. Grain Legumes. 57: 39-42.

Lal, M., P. C. Gupta and R.K. Pandey. 1988. Response of lentil to different irrigation Schedules. Lens Newsleter. 15: 20-23.

Materne, M. and A. A. Reddy. 2007. Commercial cultivation and profitability of lentil. In: Lentil: An Ancient Crop for Modern Times. Yadav S. S., D. Mcneil, P. C. Stevenson (eds.). Springer, Dordrecht, The Netherlands. Pp. 173-186.

Pratibha, G., K. G. Pillai, V. Satyanarayan and M. M. Hussain. 1996. Tillage systems for production of black gram (Vigna mungo) succeeding rice crops. Legume Res. 19: 23-28.

Sarker, B. C., M. Hara and M. Uemura. 2005. Proline synthesis, physiological responses and biomass, yield of eggplants during and after repetitive soil moisture stress. Sci. Hort. 103: 387-402.

Singh, N. B. and K. K. Verma. 1996. Response of lentil genotypes to spacing in flood prone area. Indian J. Agron. 41(4): 657-658.

Singh, R., D. K. Kundu and K. K. Bandyopadhyay. 2010. Enhancing agricultural productivity through enhanced water use efficiency. J. Agric. Phy. 10: 1-15.

Soil Survey Staff. 2003. Keys to Soil Taxonomy. $9^{\text {th }}$ edn. USDA-NRCS. US Government Printing Office, Washington, DC.

Tripathi, N. C. and N. P. Singh. 1987. Response of lentil cultivars to spacing and seeding rate. Indian J. Agron. 32(1): 1-3.

Tuti, M. D., D. Mahanta, B. L. Mina, R. Bhattacharya, J. K. Bisht and J. C. Bhatt. 2012. Performance of lentil (Lens culinaris) and toria (Brassica campestris) intercropping with wheat (Triticum aestivum) under rainfed conditions of north-west Himala 
Bandyopadhyay et al. 